TAP̈ CHÍ PHAU் TRIEÅ KH\&CN, TAR̈ 16, SOÁK1- 2013

\title{
ANTENNAS FABRICATION FOR RFID UHF AND MICROWAVE PASSIVE TAGS
}

\author{
Pham Tien Thong ${ }^{(2)}$, Nguyen Viet Hoa ${ }^{(2)}$, Tran Nhan Ai ${ }^{(1)}$, Lam Tan Phat ${ }^{(1)}$, Dang Mau Chien ${ }^{(1)}$ \\ (1) Laboratory for Nanotechnology, VNU-HCM \\ (2) University of Technology, VNU-HCM \\ (Manuscript Received on April 5 ${ }^{\text {th }}, 2012$, Manuscript Revised May 15 ${ }^{\text {th }}$, 2013)
}

\begin{abstract}
In this paper, the authors present several antenna structures for RFID passive tags with direct chip connection. In this study, the substrate is PET (Polyethylene terephthalate) with

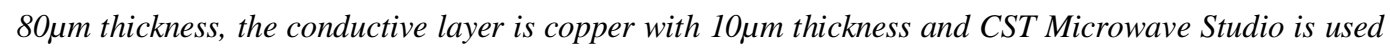
for simulation. The antenna design process is described and related results are shown. The goal of this study is to achieve compact size, good matching impedance, and to increase the bandwidth and read range of the tag as much as possible. The prototypes were fabricated by sputtering technology with $1 \mu \mathrm{m}$ thickness, then thickened by electroplating technique and finally tested by hand-held reader for read range characterizations.
\end{abstract}

Keywords: RFID; UHF RFID tag; dual-band antenna; XRAG2 chip; Atmel ATA5590 chip; radiation pattern; PET substrate.

\section{INTRODUCTION}

RFID technology is a technology perfectly suited for our ubiquitous world. To get and retrieve information on an object, tags are very useful. And they are particularly useful in the case of logistics. At the moment, there is still a large use of barcodes, but the line-of-sight reading causes various inconvenient in real environment. Nowaday, RFID is more and more interesting and already used for some applications. This paper focuses on the antenna designs for RFID passive tag in UHF band and at $2.45 \mathrm{Ghz}$. In fact, at the Laboratory for Nanotechnology (LNT), a platform for RFID research was established in order to perform studies on passive RFID tags and to realize some RFID system prototype based on the antenna design and RFID tags fabricated in our facility.

Our designs are divided into two directions: (i) first to match with XRAG2 passive chip (for first design in the UHF band) and (ii) with Atmel ATA5590 chip (for second design at $2.45 \mathrm{Ghz}$ and third design in dualband). Our target is to operate in the UHF band and at $2.45 \mathrm{Ghz}$, to have an omni-directional radiation pattern with sufficient gain, to extend the bandwidth and to increase the read range.

This paper is further organized as follows: Section II presents the antenna designs procedure using CST Microwave Studio for the antenna structures mounted with XRAG2 chip and Atmel ATA5590 chip. The fabrication process, the tag prototype, the result of the measurement and the read range are shown in 
this section. And finally, the conclusions are given in Section III.

\section{ANTENNA DESIGN PROCEDURE}

The first attempt has been made for applications in UHF band using XRAG2 chip having the input impedance of 23-180j Ohm at 915 Mhz. With this antenna, the first task was to made the resonant frequency be in UHF band, therefore thestudy about theresonant frequencyoftheantennaon the PET substrate have to be done. Through the simulation, it was found that the resonant frequencyofthe antennawouldbe shiftedafter mounting thechip. So aloopof about $75 \mathrm{mmat} 868 \mathrm{MHz}$ was chosen as the first component of the antenna structure. After having the desired resonant frequency, next is to focus on the impedance matching and

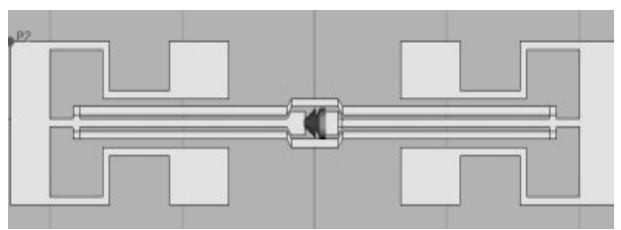

a)

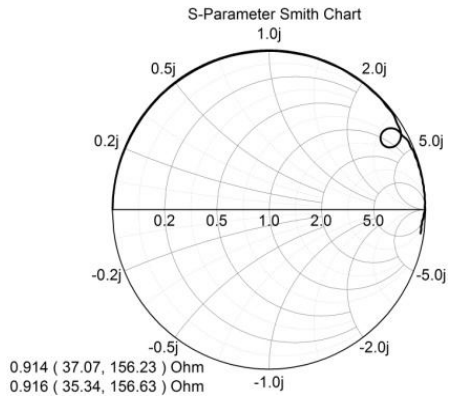

c) on expanding thebandwidthof theantenna. Withdoubleloop, the impedance matching would be better but dimensions of the loop have to be adjusted for obtaining the desired resonant frequency. To expand the bandwidth, the second resonant frequency was created by adding the tip-load [1], [2]. And then, the second resonant frequency was moved close to the first one by adjusting the tip-load's size. After analyzing the influence of the dimensions of antenna, it is noted that increasing the lengthand reducing the width of the loop can compactthe size but stillachievethe desiredresonant frequencywhile the return loss is better. Besides, using four symmetrical tiploadsis easiertopull the resonant frequenciesas wellas to have better matchingimpedance.

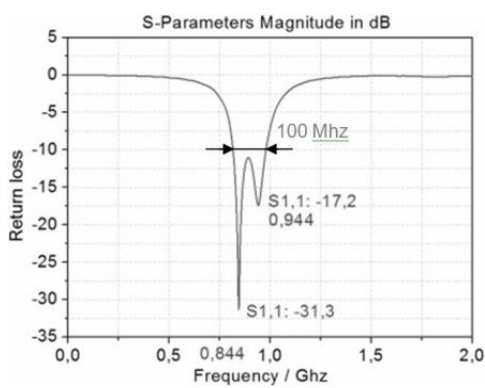

b)

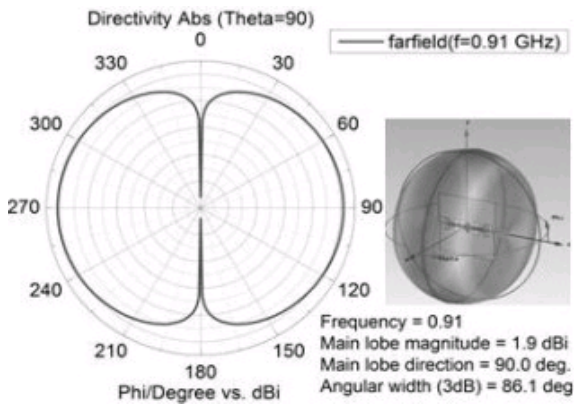

d)

Figure 1. a) The first antenna and its, b) Return loss, c) Impedance smith chart, d) Radiation pattern. 
In the following step, the parameters of some components were varied to optimize the resonant frequencyand the matching impedance withthe chip. The first antenna structure with its radiation characteristics are shown in Fig. 1.

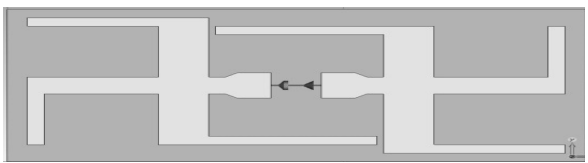

a)

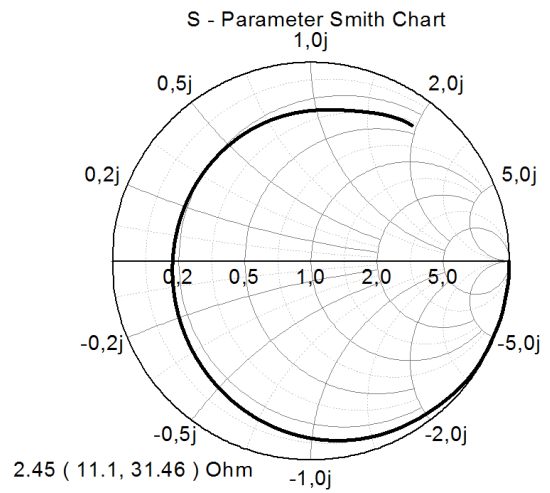

c)
The bandwidthof $-10 \mathrm{~dB}$ is around $100 \mathrm{Mhz}$, covers the UHF band for RFID. The impedance matching is not good but can be accepted. And the radiation pattern is good with the gain of $1.9 \mathrm{dBi}$.

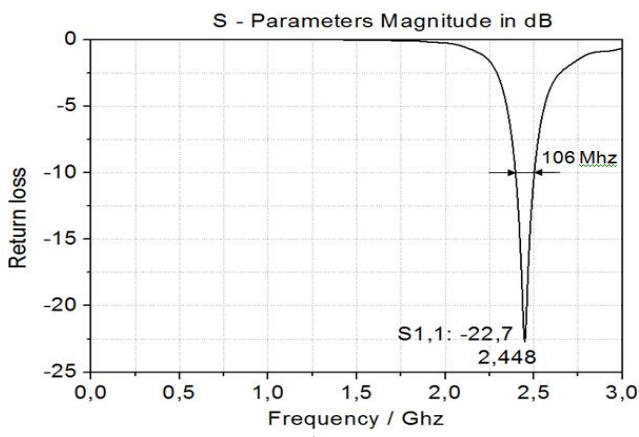

b)

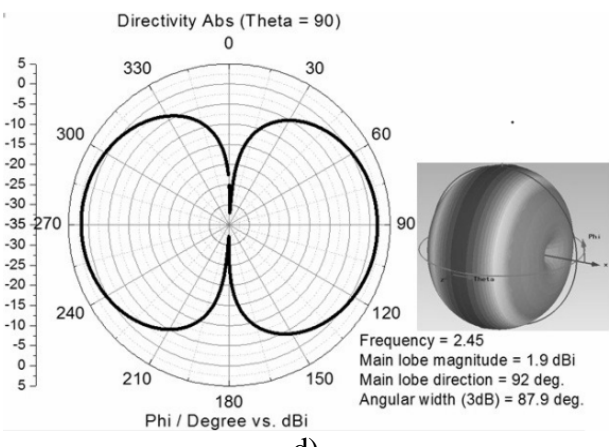

d)

Figure 2. a) The second antenna and its, b) Return loss,c) Smith chart, d) Radiation pattern.

Our second design was matched with the Atmel ATA5590 chip having the input impedance of $10.5-143 \mathrm{j} \mathrm{Ohm}$ at $915 \mathrm{Mhz}$ and $10-31 \mathrm{j}$ Ohm at $2.45 \mathrm{Ghz}$. This design was just focused at $2.45 \mathrm{GHz}$, so the compact size problem was already done since the higher working frequency gives the smaller antennas structure. With this frequency, the design began from straight dipole configuration [1-4] with the length of about $32 \mathrm{~mm}$. The length and width of dipole was adjusted to obtain the desired resonant frequency. And then, the other components as the jamb, the stub were added to match impedance with chip. These components did not affect too much to radiation pattern of antenna. Besides, they can extend the bandwidth of antenna. 


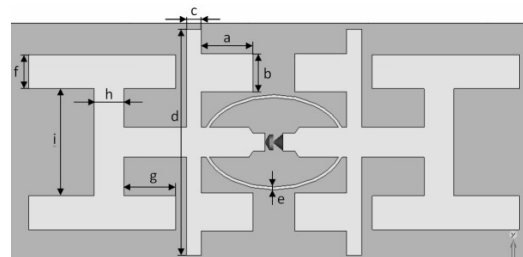

a)

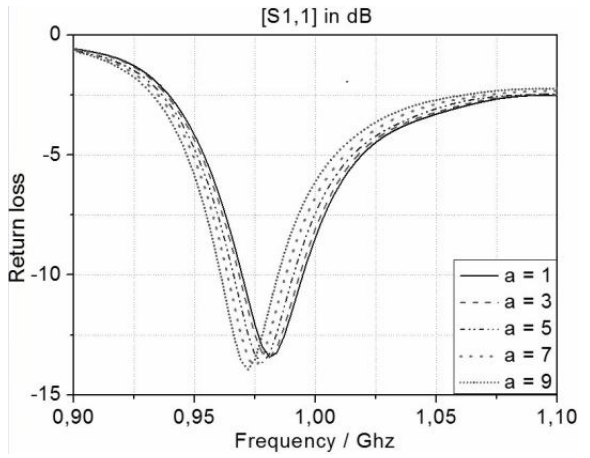

c)

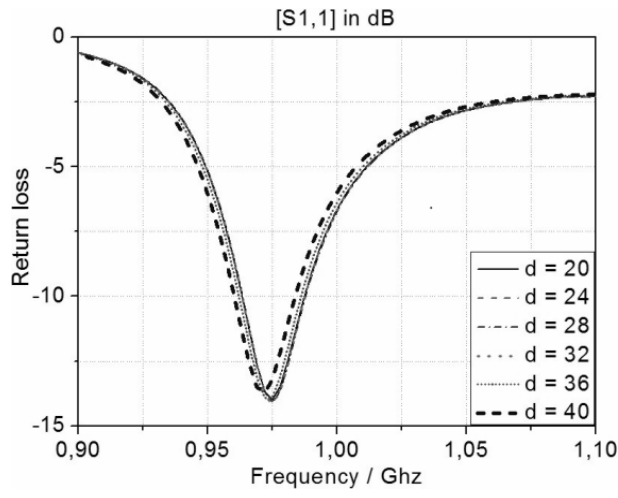

e)

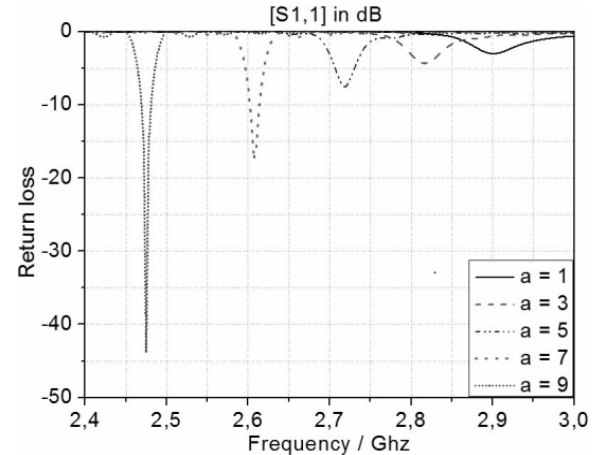

b)

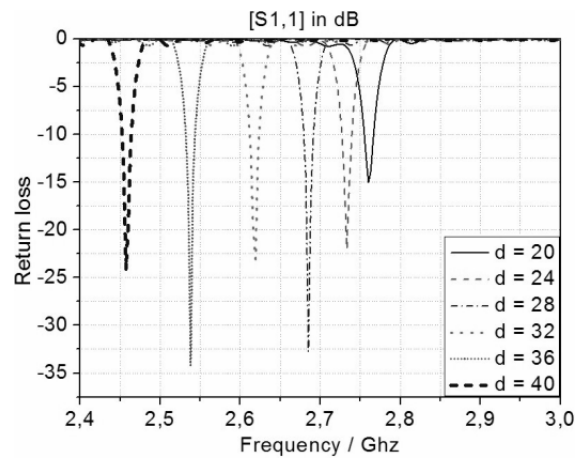

d)

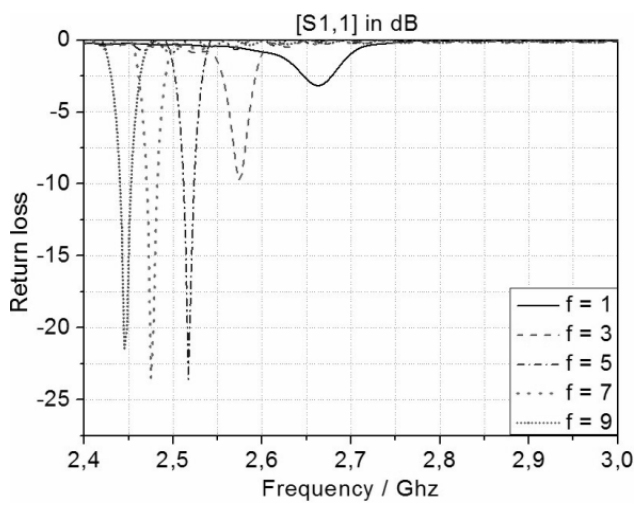

f) 


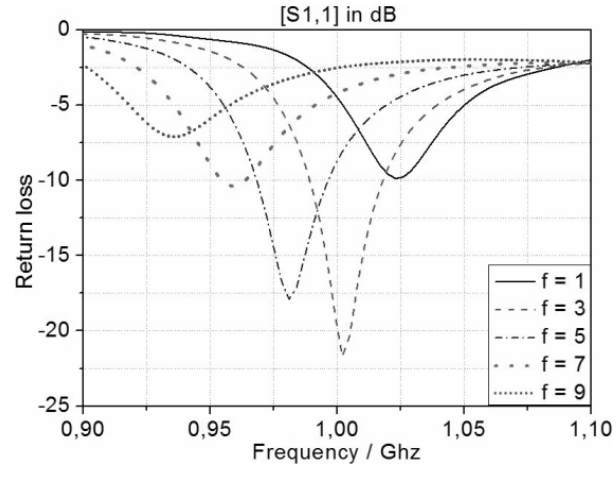

g)

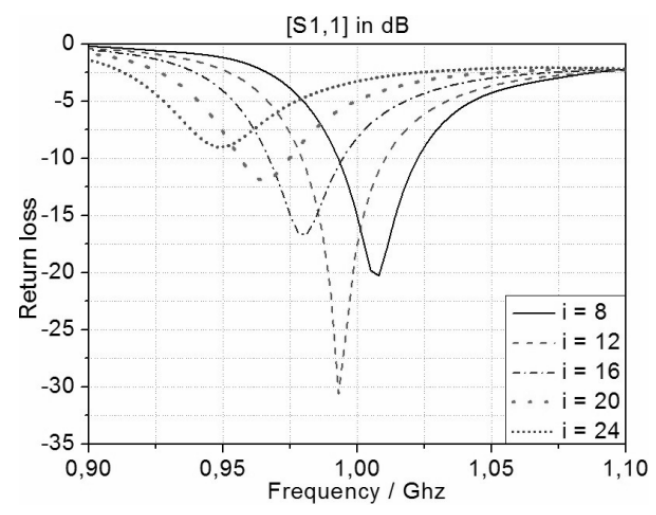

i)

At last, though simulations, the parameters of antenna were adjusted again to optimize the characteristics. The second design and its characteristics are shown in Fig. 2. The bandwidth of $-10 \mathrm{~dB}$ is around $106 \mathrm{Mhz}$, ensures the tag can work properly at $2.45 \mathrm{Ghz}$. The impedance matching has a good result for simulation and the radiation pattern is good too with the gain of $1.9 \mathrm{dBi}$.

Our next antenna was also designed with Atmel ATA5590 chip, but it was supposed to have dual-band antenna feature [5]. It has two resonant frequencies: one in UHF band and another at $2.45 \mathrm{GHz}$. This design had the same

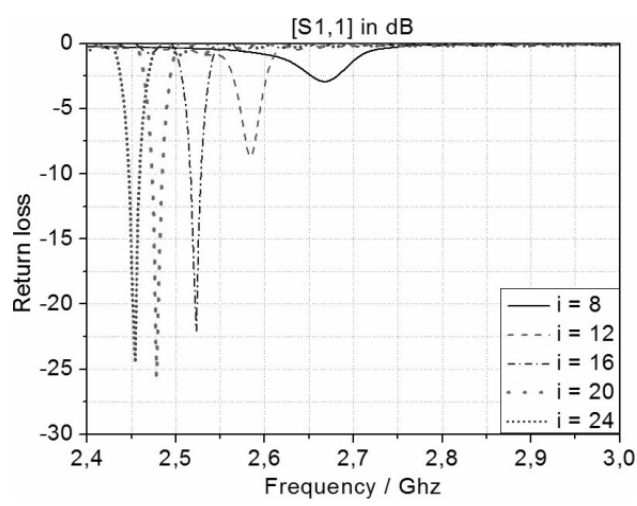

h)

Figure 3. a) The third antenna, b) Effect of "a" at 2.45 Ghz, c) Effect of "a" in UHF band, d) Effect of "d" at 2.45 Ghz, e) Effect of "d" in UHF band, f) Effect of "f" at $2.45 \mathrm{Ghz}, \mathrm{g})$ Effect of "f" in UHF band, h) Effect of

"i" at 2.45 Ghz, i) Effect of "i" in UHF band

initial idea with the second design, use a straight dipole for the first resonant frequency. And then, a circle component was added, it links two parts of dipole together. This made the second resonant frequency to be appeared. But these resonant frequencies were not in correct positions. Therefore, the jamb and the stub were added to obtain the desired resonant frequencies and to match impedance with chip. And finally, the parameters of the antenna were adjusted to obtain the best result.

It is noted that this is a dual-band antenna, so this antenna was matched with impedance of the chip in UHF band and at $2.45 \mathrm{GHz}$ 
independently. The components that are close the chip (except the circle) effects to characteristics of antenna at $2.45 \mathrm{GHz}$ so much, but almost does not effect in UHF band. And the other components effect to characteristics of antenna in both bands. The third design and some effects of the antenna's parameters are shown in Fig. 3 (all dimensions are in $\mathrm{mm}$ ).

From Fig. $3 b$ and $3 c$, it is found that the return loss at $2.45 \mathrm{Ghz}$ is affected strongly by "a". But in UHF band, the effect of "a" is very small. In Fig. 3d and 3e, the return loss at 2.45 Ghz is also affected by "d", but the effect is not as strong as in case "a". Because of "a" is closer to chip than "d". And in UHF band, the effect of "d" is almost nothing. From Fig. 3f, $3 \mathrm{~g}, 3 \mathrm{~h}$ and $3 \mathrm{i}$, it is obviously that the effects of "i" and "f" on the return loss at $2.45 \mathrm{Ghz}$ are weaker. But in UHF band, it is found that the effects are stronger. With this design, "a" has a strongest effect on the return loss at 2.45 Ghz.Therefore, it can be used to adjustfor impedance matching at $2.45 \mathrm{Ghz}$ first. And then, the others will be used to match impedance in UHF band. And its characteristics are shown in Fig. 4. The bandwidth of $-10 \mathrm{~dB}$ is around $26 \mathrm{Mhz}$ in $\mathrm{UHF}$ band and the return loss at near $2.45 \mathrm{Ghz}$ is -
$10.7 \mathrm{~dB}$, but it can be still accepted. The impedance matching is not good but it ensures that it is for both bands. The radiation pattern at 2.45 Ghz is rather distorted, but with the high gain of $3.6 \mathrm{dBi}$, it can be compensate for the bad return loss. And the radiation pattern in UHF band is good with the gain of $1.9 \mathrm{dBi}$.

The testing the first antenna with $500 \mathrm{~mW}$ hand-held reader was performed, the maximum read range about $60 \mathrm{~cm}$ was obtained.

The prototypes have been made at Laboratory for Nanotechnology (LNT), VietnamNationalUniversity - Ho Chi Minh Cityby sputtering technology. And then, they have been tested by using Rohde \& Schwarz ZVB Vector Network Analyzer available at Department of Telecommunication Engineering, HCMC University of Technology. The real antennas areFigure 3.shown in Fig. 5a,5b,5c. And the experimental results of the antennas are shown in Fig. 6. The obtained results in UHF band are rather similar to the simulated results, but they are not really good at $2.45 \mathrm{Ghz}$. In the measurement process, the measured conditions which are not good enough for measuring at $2.45 \mathrm{Ghz}$ can make this distortion. 


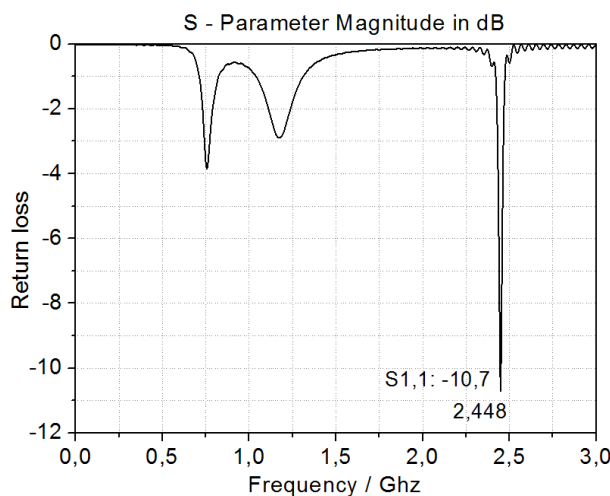

a)

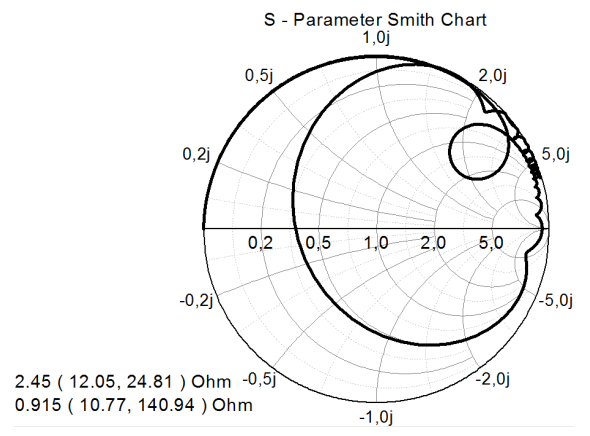

c)

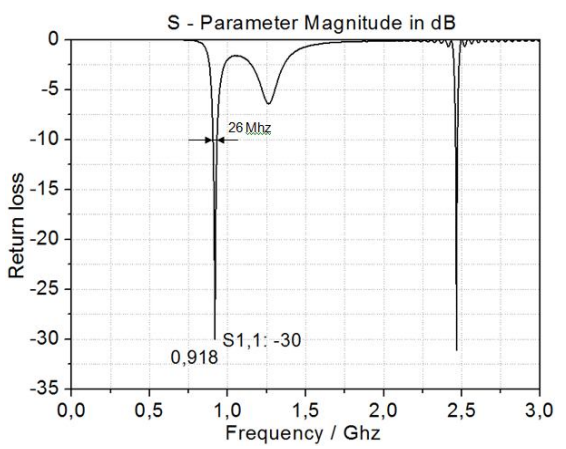

b)

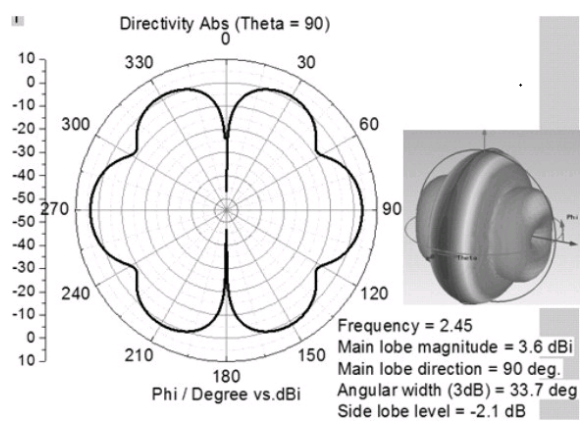

d)

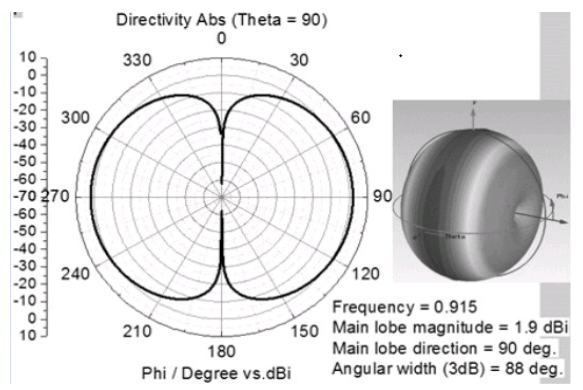

e)

Figure 4. a) Return loss at $2.45 \mathrm{Ghz}$; b) Return loss in UHF band ; c) Impedence smith chart ; d) Radiation pattern at $2.45 \mathrm{Ghz}$; e) Radiation pattern in UHF band. 


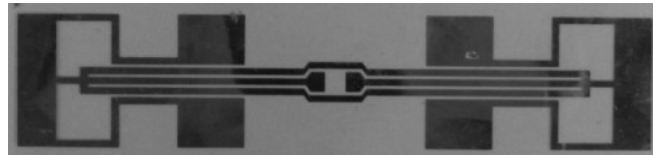

a)

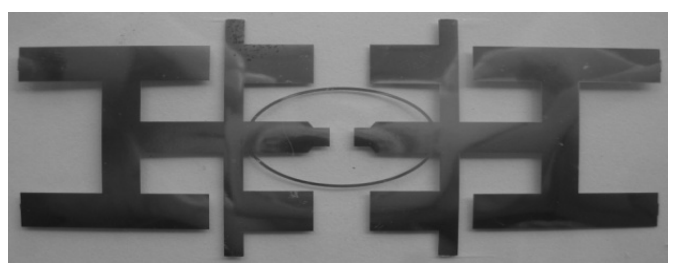

c)

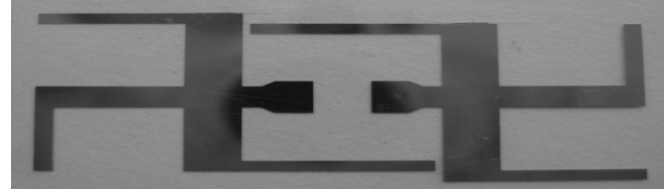

b)

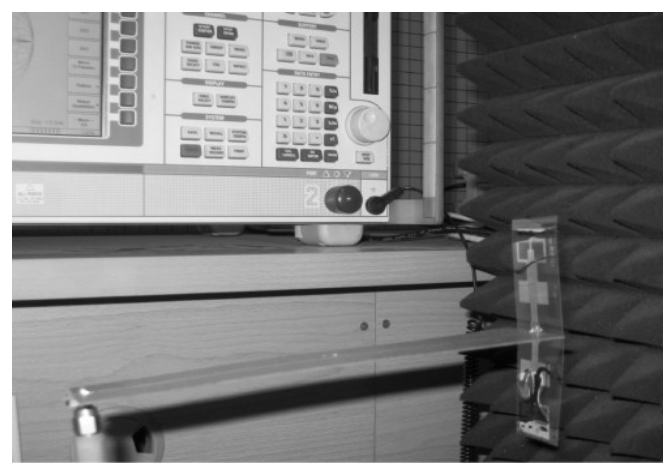

d)

Figure 5. a) The prototype of the first antenna, b) The prototype of the second antenna, c) The prototype of the third antenna, d) Measuring the impedance of antenna using Rohde \& Schwarz ZVB Vector Network Analyzer.

\section{CONCLUSIONS}

In this paper, the antenna design processes with direct chip connection have been presented. With all designs, we try to obtain the best impedance matching in UHF band (860$960 \mathrm{Mhz}$ ) and at $2.45 \mathrm{Ghz}$. Three antenna structures have been designed and fabricated with size can be fixed in an identification card. The first design has large bandwidth cover all frequency in UHF band, this advantage make this antenna can be applied in many countries. The second and third designs are prospective designs for applications at $2.45 \mathrm{Ghz}$ and in dual-band. These tags can be fabricated easily and some of them can be tested by hand-held reader with the maximum read range can be as far as $60 \mathrm{~cm}$. These tags are entirely possible to be realized in practice. In future, we hope to optimize these designs to obtain better characteristics. 


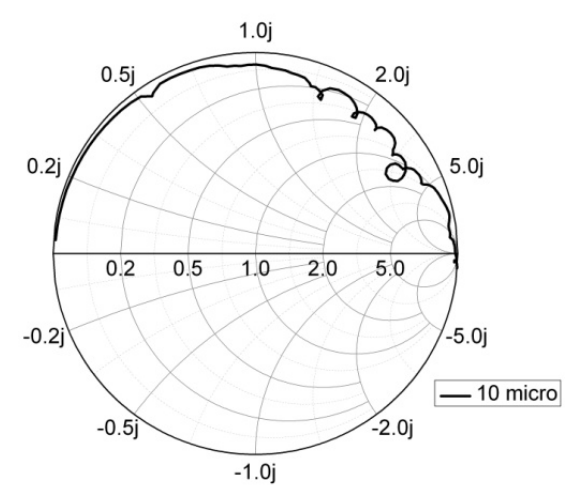

a)

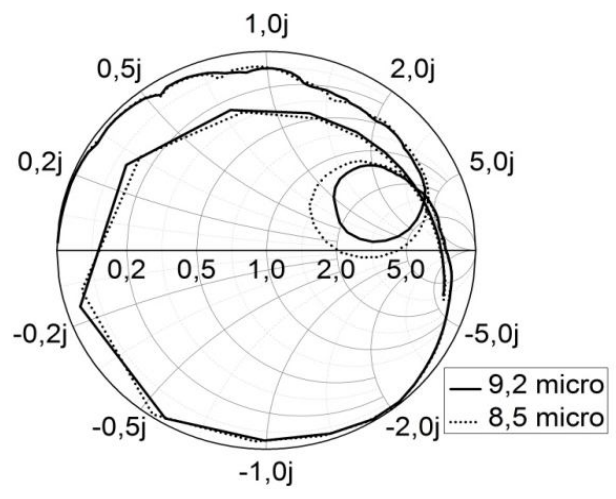

c)

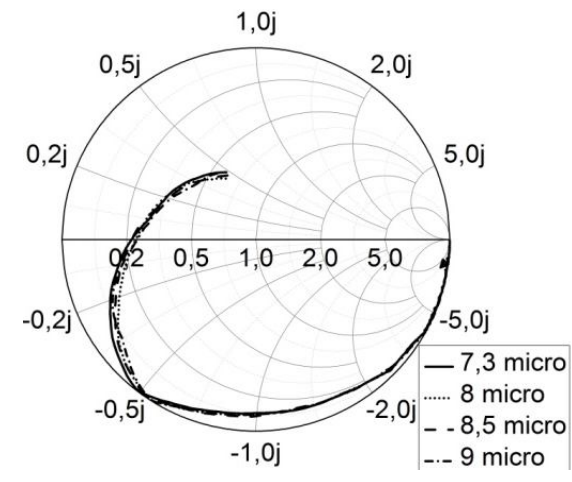

b)
Figure 6. Measured input impedance of: a) the first antenna with various thicknesses; $b$ ) the second antenna with various thicknesses; c) the third antenna with various thicknesses.

\title{
CHẾ TẠO ĂNG-TEN CHO THẺ RFID THỤ ĐộNG Ở BĂNG TẦN UHF VÀ VI BA
}

\author{
Phạm Tiến Thông ${ }^{(2)}$, Nguyễn Viết Hòa ${ }^{(2)}$, Trần Nhân Ái ${ }^{(1)}$, Lâm Tấn Phát ${ }^{(1)}$, Đặng Mậu Chiến ${ }^{(1)}$ \\ (1) Phòng thí nghiệm Công nghệ Nano, ĐHQG-HCM
}

(2) Trường Đại học Bách Khoa, ĐHQG-HCM

TÓM TÄT: Trong bài báo này, chúng tôi đưa ra một vài cấu trúc ăng-ten cho thẻ RFID thu động với quy trình kết nối chíp trục tiếp. Trong nghiên cứu này, lớp đế đự̛c sử dụng là PET (Polyethylene terephthalate) với độ dày là $80 \mu m$; dải dân làm bằng đồng với độ dày là $10 \mu m$; và phần mềm được sử dụng để mô phỏng là CST Microwave Studio. Quá trình thiết kế ăng-ten đuợc trình bày kỹ càng và các kết quả liên quan cũng được đưa ra. Muc tiêu của nghiên cứu này là cố gắng tạo ra thẻ nhận dạng có kích thuớc bé, phối hợp trở kháng tốt, và quan trọng là băng thông và tầm đọc của thẻ càng tăng nhiều càng tốt. Các mẫu chế tạo được thực hiện bằng phuơng pháp phún xạ với độ dày lum, 
sau đó được tiếp tục làm dày bằng phuơng pháp điện hoá và cuối cùng đuợc kiểm tra tầm đọc bằng đầu đọc cầm tay.

Tù̀ khoá: RFID; thẻ UHF RFID; ăng-ten hai băng tần; chíp XRAG2; chíp Atmel ATA5590; đồ thị bức xa; đế PET.

\section{REFERENCES}

[1]. Daniel Dobkin, The RF in RFID: Passive UHF RFID in Practice, Newnes(2008).

[2]. Vuong Ho Cong Tam, Antenna design for UHF RFID Passive tags, Graduation thesis, University of Technology - VNU HCM (2011).

[3]. Gaetano Marrocco, The art of UHF RFID antenna design: impedance matching and size - reducing technequis, IEEE antennas and propagation magazine, Vol.50, N.1(2008).
[4]. K. V. S. Rao, P. V. Nikitin, and S. F. Lam, Antenna design for UHF RFID tags: A review and a practical application, IEEE Transactions and Propagation, Vol. 53, no. 12 , 3870-3876 (2005).

[5]. Daniel D. Deavours, Analysis and Design of Wideband Passive UHF RFID Tags Using a Circuit Model, IEEE Conference on RFID, 283 - 290, USA (2009). 